\title{
Occupational risk factors for upper respiratory tract and upper digestive tract cancers
}

\author{
JM Haguenoer, S Cordier, C Morel, JL Lefebvre, D Hemon
}

\begin{abstract}
A case-control study was conducted to investigate occupational risk factors for upper respiratory and digestive tract cancers (nose, lips, buccal cavity, pharynx, and larynx) in the north of France. Two hundred and eighty three cases of histologically confirmed cancer in men treated during the first semester of 1983 at the Regional Cancer Institute were included in the study. Two controls per case were chosen from patients in the medical wards of the local general hospitals in the same geographical area as the case, who did not have cancer. Controls were individually matched for sex, age ( \pm 18 months), ethnic group, area of residence, and smoking and alcohol drinking history. All subjects were questioned about occupations in which they had worked for at least 15 years. Odds ratios for major occupational categories were estimated using conditional logistic regression for matched samples. Significant associations were found between wood work and nasal cancer (four cases, no control) and farming and lip cancer (odds ratio $5 \cdot 3,95 \%$ confidence interval $1 \cdot 1$ 26.8). Pharyngeal cancer was associated with the textile industry $(\mathrm{OR} 2 \cdot 4,95 \% \mathrm{CI} 1 \cdot 0-5 \cdot 7)$ and the building industry (OR $2 \cdot 0,95 \%$ CI 1.1-3.9). Coal miners showed a threefold excess risk for cancer of the lip ( 4 cases, no control), buccal cavity (OR 3.5 , 95\% CI 1.1-11.8), and larynx (OR 3·2, 95\% CI 1·1-9.7).
\end{abstract}

Mortality from upper respiratory and digestive tract (URDT; nose and sinus, lips, buccal cavity, pharynx, and larynx) cancers in men is higher in France than in all other western countries (27.4 per 100000 in 1977 compared with 12.5 in Italy which ranks second, and

IMT, Région du Nord, Faculté de Médecine, 59045 Lille Cédex, France

JM Haguenoer, C Morel

INSERM U 170, 94807 Villejuif Cédex

S Cordier, D Hemon

Centre de Lutte contre le Cancer du Nord de la France, 59020 Lille Cédex

JL Lefebvre
3.5 in Sweden), and has increased during the past $20 \vec{\omega}$ years. ${ }^{1}$ Comparisons of incidence rates from the available registries show the same trends. ${ }^{2}$ Within $\frac{\Phi}{7}$ France, mortality from URDT cancers in men is higher in the north and in Brittany. ${ }^{3}$ The same. observations for oesophageal cancer prompted a study which showed the major part played by alcohol and tobacco consumption in the aetiology of this cancer. ${ }^{4}$ No doubt the high incidence of URDT ${ }^{\circ}$ cancers in the north of France might also be partly $\vec{c}$ explained by regional alcohol drinking and smoking habits. Considering the high level of industrial $\stackrel{\Phi}{\Phi}$ activity in this area, however, a case-control study $\overrightarrow{0}$ was undertaken to investigate the possible role of $\%$ occupational factors in URDT cancers, taking into account alcohol and tobacco consumption.

\section{Methods}

Two hundred and eighty three men treated during $\overline{0}$ the first semester of 1983 for histologically confirmed primary URDT cancer at the Regional Cancer Institute were included in our study. This institute is the only centre of its type in the north of France (Nord-Pas de Calais region), and treats over two 3 thirds of URDT cancer patients diagnosed in the region. Examination of the statistics of admission showed no bias for selection on socioprofessional of characteristics compared with the region as a whole. Two hundred and thirty four patients $(82.6 \%)$ had $ᄋ$ been diagnosed less than one year before inclusion in $\rightarrow$ the study.

For each case two men were chosen as controls from patients in the wards of internal medicine of local general hospitals in the same geographical area $\mathbb{O}$ as the case, who did not have cancer. Controls were $\underset{\omega}{N}$ individually matched for age ( \pm 18 months), country 0 of origin (France, southern Europe, eastern Europe, 0 north Africa), area of residence, and smoking and $\frac{D}{D}$ alcohol drinking history. Tobacco consumption was $\stackrel{\mathcal{P}}{+}$ expressed as cigarette equivalents (one pipe $=$ two $\square$ cigars $=$ four cigarettes). Matching was done $\bar{O}$ separately on class of average daily tobacco consump- $\stackrel{\mathbb{Q}}{\Omega}$ tion (non-smoker or ex-smoker for more than five $\mathbb{\otimes}$ years, one to nine cigarettes a day, 10-19 cigarettes a day, $\geqslant 20$ cigarettes a day) and number of years smoked ( \pm five years). Alcohol drinkers were 
matched according to four groups of average daily consumption (occasional drinkers, $<44 \mathrm{~g}$ a day, $44-88 \mathrm{~g}$ a day, $>88 \mathrm{~g}$ a day; equivalents of pure alcohol, 11 wine $=88 \mathrm{~g}, 11$ beer $=44 \mathrm{~g}, 1$ measure spirits $=15 \mathrm{~g}$ ). Potential controls were first interviewed about their smoking and alcohol drinking habits; if matching was not achieved the interview was not completed.

The causes for entering hospital among the 566 controls were cardiovascular diseases $(25 \%)$, metabolic diseases $\left(17_{0}^{\circ}\right)$, infectious diseases $(16 \%)$, digestive problems $\left(15^{\circ}{ }_{0}\right)$, neurological disorders $\left(8^{\circ}{ }_{0}\right)$, skeletomuscular diseases $\left(8^{\circ}{ }_{0}\right)$, and miscellaneous diseases $\left(11^{\circ}{ }_{0}\right)$.

Cases and controls were interviewed while in hospital by the same person (CM) about their smoking and alcohol drinking history and about the occupations in which they had worked for at least 15 years. Subjects who had not worked in the same type of job for at least 15 years were not included in the study. This led to the exclusion of half the subjects.

Types of occupation were classified into 11 groups-namely, coal mining, the building industry, metal work and mechanics, agriculture, road transport, shipping, the textile industry, wood work, road works, service industries, and others. Only two people had held two different jobs for more than 15 years each and they were assigned to both groups in which they had worked. Odds ratios for having worked in each occupational group were calculated using the Mantel-Haenszel estimation and conditional logistic regression for matched samples. ${ }^{5}$

\section{Results}

Table 1 describes the different sites and histological types of URDT cancers included in the study. Cancers of the pharynx, buccal cavity, and larynx

Table 1 Distribution of cases by site and histological type for URDT cancers

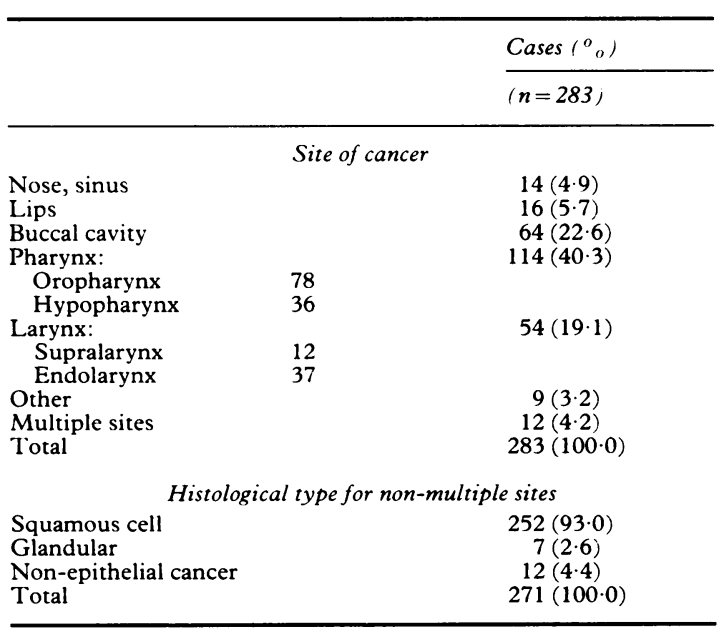

Table 2 Distribution of cases and controls according to tobacco and alcohol consumption

\begin{tabular}{lcc}
\hline & $\begin{array}{c}\text { Cases }(\%) \\
(n=283)\end{array}$ & $\begin{array}{l}\text { Controls }(\%) \\
(n=566)\end{array}$ \\
\hline \multicolumn{4}{c}{ Tobacco consumption (pack-years) } \\
0 & $9(3 \cdot 2)$ & $17(3 \cdot 0)$ \\
$1-19$ & $52(18 \cdot 4)$ & $95(16 \cdot 8)$ \\
$20-39$ & $134(47 \cdot 5)$ & $268(47 \cdot 5)$ \\
$40-59$ & $45(16 \cdot 0)$ & $110(19 \cdot 5)$ \\
$\geqslant 60$ & $43(15 \cdot 2)$ & $76(13 \cdot 4)$ \\
& & \\
Occasional drinker & Alcohol consumption $(g /$ day) & \\
$<44$ & $42(14 \cdot 8)$ & $85(15 \cdot 0)$ \\
$44-88$ & $48(17 \cdot 0)$ & $95(16 \cdot 8)$ \\
$>88$ & $96(33 \cdot 9)$ & $192(33 \cdot 9)$ \\
& $97(34 \cdot 3)$ & $194(34 \cdot 3)$ \\
\hline
\end{tabular}

accounted for more than $80^{\circ}{ }_{0}$ of the cases. Ninety three per cent of the cancers were squamous cell carcinomas.

Close matching was achieved between patients with cancer and controls for country of origin $(92 \%$ of patients were French), area of residence, age at interview (mean age 58.3 years), and tobacco and alcohol consumption (table 2). Tobacco consumption was slightly lower, and alcohol consumption was much higher than in other case-control studies on oral cavity, pharyngeal, or laryngeal cancers published in the United States and Canada.

Table 3 shows the odds ratio estimates for 11 occupational groups for all sites of cancer combined. These ratios compare the risk of disease for people who worked in these occupations for more than 15 years with the risk of disease for people who never worked in these occupations or those who worked for less than 15 years. Relative risks were significantly greater than one among coal miners, workers in the building industry, and wood workers. Relative risk of URDT cancers for service industries was significantly lower than one.

Analyses related to specific sites of cancer are presented in table 4 . Among 14 cases of nose and sinus cancer, four were wood workers. Three had

Table 3 Estimates of odds ratios for different occupational groups for all sites of cancer combined

\begin{tabular}{|c|c|c|c|c|}
\hline $\begin{array}{l}\text { Occupational } \\
\text { group }\end{array}$ & $\begin{array}{l}\text { Cases } \\
(n=283)\end{array}$ & $\begin{array}{l}\text { Controls } \\
(n=566)\end{array}$ & $\begin{array}{l}\text { Odds } \\
\text { ratio }\end{array}$ & $\begin{array}{l}95^{\circ}{ }^{\circ} \\
\text { Confidence } \\
\text { interval }\end{array}$ \\
\hline Mining & 48 & 52 & $2 \cdot 6^{\star}$ & $1 \cdot 6-4 \cdot 3$ \\
\hline Building industry & 53 & 59 & $2 \cdot 0^{\star}$ & $1 \cdot 3-3 \cdot 0$ \\
\hline $\begin{array}{l}\text { Metal work, } \\
\text { mechanics }\end{array}$ & 44 & 83 & $1 \cdot 1$ & $0 \cdot 7-1 \cdot 6$ \\
\hline Agriculture & 18 & 42 & 0.9 & $0.5-1.5$ \\
\hline Road transport & 17 & 37 & 0.9 & $0 \cdot 5-1 \cdot 7$ \\
\hline $\begin{array}{l}\text { Shipping and } \\
\text { seamen }\end{array}$ & 14 & 32 & $0 \cdot 8$ & $0 \cdot 4-1 \cdot 7$ \\
\hline Textile industry & 17 & 27 & $1 \cdot 3$ & $0 \cdot 7-2 \cdot 5$ \\
\hline Wood work & 10 & 7 & $3 \cdot 5^{\star}$ & $1 \cdot 2-10 \cdot 3$ \\
\hline Road works & 13 & 27 & $1 \cdot 0$ & $0.5-1.9$ \\
\hline Service industries & 45 & 179 & $0 \cdot 4^{\star}$ & $0 \cdot 3-0 \cdot 6$ \\
\hline Others & 7 & 21 & $0 \cdot 7$ & $0 \cdot 3-1 \cdot 6$ \\
\hline
\end{tabular}

*Odds ratio significantly different from one $(p<0.05)$. 
Table 4 Estimation of odds ratios by occupational group for each site of cancer (No of exposed cases/No of exposed controls in parentheses)

\begin{tabular}{|c|c|c|c|c|c|c|c|}
\hline & $\begin{array}{l}\text { Nose } \\
\text { sinus } \\
(n=14)\end{array}$ & $\begin{array}{l}\text { Lips } \\
(n=16)\end{array}$ & $\begin{array}{l}\text { Buccal } \\
\text { cavity } \\
(n=64)\end{array}$ & $\begin{array}{l}\text { Pharynx } \\
(n=114)\end{array}$ & $\begin{array}{l}\text { Larynx } \\
(n=54)\end{array}$ & $\begin{array}{l}\text { Multiple } \\
\text { sites } \\
(n=12)\end{array}$ & $\begin{array}{l}\text { All sites } \\
(n=283)\end{array}$ \\
\hline $\begin{array}{l}\text { Mining } \\
\text { Building industry } \\
\text { Metal work, mechanics } \\
\text { Agriculture } \\
\text { Road transport } \\
\text { Shipping and seamen } \\
\text { Textile industry } \\
\text { Wood work } \\
\text { Road works } \\
\text { Service industries } \\
\text { Others }\end{array}$ & $\begin{array}{l}6 \cdot 0(3 / 1) \\
0(0 / 4) \\
-(3 / 0) \\
1 \cdot 3(2 / 3) \\
1 \cdot 0(1 / 2) \\
0(0 / 2) \\
0(0 / 1) \\
\overbrace{}^{\star}(4 / 0) \\
0(0 / 2) \\
0.2(1 / 11) \\
0(0 / 2)\end{array}$ & $\begin{array}{l}C^{\star}(4 / 0) \\
2 \cdot 4(3 / 3) \\
0(0 / 5) \\
5 \cdot 3^{\star}(6 / 3) \\
0(0 / 2) \\
0(0 / 1) \\
0(0 / 2) \\
0(0 / 2) \\
2 \cdot 7(2 / 2) \\
0 \cdot 1^{\star}(1 / 11) \\
0(0 / 1)\end{array}$ & $\begin{array}{l}3 \cdot 5^{\star}(11 / 11) \\
1 \cdot 9(12 / 14) \\
1 \cdot 2(13 / 22) \\
0 \cdot 3(1 / 7) \\
0 \cdot 8(4 / 10) \\
0 \cdot 5(3 / 9) \\
0 \cdot 7(2 / 5) \\
1 \cdot 3(2 / 3) \\
2 \cdot 2(5 / 5) \\
0 \cdot 5(11 / 39) \\
0 \cdot 7(1 / 3)\end{array}$ & $\begin{array}{l}1 \cdot 4(17 / 28) \\
2 \cdot 0^{\star}(21 / 23) \\
0 \cdot 7(16 / 42) \\
0 \cdot 5(4 / 15) \\
0 \cdot 8(6 / 15) \\
1 \cdot 0(5 / 10) \\
2 \cdot 4^{\star}(12 / 11) \\
-(4 / 1) \\
1 \cdot 8(5 / 6) \\
0 \cdot 5^{\star}(20 / 67) \\
1 \cdot 0(5 / 10)\end{array}$ & $\begin{array}{l}3 \cdot 2^{\star}(11 / 10) \\
1 \cdot 5(8 / 11) \\
1 \cdot 8(7 / 8) \\
1 \cdot 0(5 / 10) \\
2 \cdot 2(6 / 6) \\
1 \cdot 8(6 / 8) \\
0.3(1 / 6) \\
0(0 / 1) \\
0.2(1 / 10) \\
0.4^{\star}(8 / 34) \\
0.5(1 / 4)\end{array}$ & $\begin{array}{l}-(2 / 1) \\
Z^{\star}(8 / 2) \\
1 \cdot 6(3 / 4) \\
0(0 / 3) \\
0(0 / 1) \\
0(0 / 1) \\
0(0 / 1) \\
-(0 / 0) \\
0(0 / 2) \\
0(0 / 8) \\
0(0 / 1)\end{array}$ & $\begin{array}{l}2 \cdot 6^{\star}(48 / 52) \\
2 \cdot 0^{\star}(53 / 59) \\
1 \cdot 1(44 / 83) \\
0 \cdot 9(18 / 42) \\
0.9(17 / 37) \\
0 \cdot 8(14 / 31) \\
1 \cdot 3(17 / 27) \\
3 \cdot 5^{\star}(10 / 7) \\
1 \cdot 0(13 / 27) \\
0 \cdot 4^{\star}(45 / 179) \\
0.7(7 / 21)\end{array}$ \\
\hline
\end{tabular}

*Odds ratio significantly different from one $(p<0.05)$; -indeterminate (matched odds ratio could not be computed).

cancer of the ethmoids and one had cancer of the maxillary sinus. Relative risk for cancer of the lip was significantly greater than one among coal miners and among farmers. The only significant excess risk of cancer of the buccal cavity was among coal miners who were also at higher relative risk for laryngeal cancer. A significant relative risk of pharyngeal cancer was shown among workers in the building industry and in the textile industry.

\section{Discussion}

It is appreciated that restricting choice of subjects to those who had held one job for at least 15 years introduced a selection; it was the same, however, for both cases and controls. Such a selection precluded the study of short term exposures of employees, and of more recent industrial activities. In computing the odds ratio for a particular occupational group the reference category could include men who had worked in the same group for less than 15 years, or in other occupational groups potentially at risk, and this could bias the results. This seldom happened, however, as employment in the region is stable, and the number of years spent in the reported occupations covered most of the working life of both cases and their matched controls. Furthermore, the choice of this reference category tends to underestimate the relative risks.

\section{NOSE AND LIPS}

The associations found in the nose and lips are already established. For instance, the association between exposure to wood dust and nasal cancer has been reported ${ }^{6}$ and lip cancer has been shown to be more frequent among people working outdoors, especially farmers. ${ }^{7}$

\section{PHARYNX}

In the present study an excess risk of pharyngeal cancer was seen among workers in the textile industry and occurred in a spread of subgroups- namely, spinners and winders ( 4 cases, 5 controls), weavers ( 2 cases, 3 controls), pressers ( 1 case, no control), maintenance workers ( 2 cases, 1 control), 윽 and unknown occupations ( 3 cases, 2 controls). Excess risk was also found in workers in the building industry.

An excess of oral and pharyngeal cancer among $\vec{\theta}$ textile workers in England has been reported previously, ${ }^{8}$ but this was not confirmed by a later study. ${ }^{9}$ Leather work was associated with cancer of the buccal cavity, pharynx, and larynx, ${ }^{10}$ and Elwood and colleagues reported a moderately increased relative risk for these cancers in men with a history of working in the logging and mining industries. ${ }^{11}$ More recently, a study carried out in France on workers producing manmade mineral fibres showed them to have an excess risk for cancer of the pharynx, the buccal cavity, and the larynx. ${ }^{12}$

Work in the building industry involves various types of exposure, especially to cement dust and insulation material, which might influence the occurrence of pharyngeal cancer in workers from this industry. In our study 15 cases and 11 controls working in the building industry had jobs involving heavy dust exposure (masons, tile layers, plasterers), 음 compared with less dusty jobs (painters, electricians, $>$ plumbers) in which six cases and 12 controls had worked.

LARYNX

Occupational risk factors for iaryngeal cancer have $N$ been extensively studied. Asbestos, nickel refining, $\sigma$ wood dust, mustard gas manufacturing, isopropyl alcohol, leather work, and sulphuric acid have all $\frac{\mathrm{C}}{\mathrm{D}}$ been associated with an excess risk of laryngeal $\stackrel{\oplus}{+}$ cancer. ${ }^{13}$ More recently, an increased relative risk was $\square$ found among farmers and textile processors. ${ }^{14}$ Olsen $\bar{O}$ and colleagues in Denmark reported high relative $\mathbb{D}$ risks among workers exposed to dust, drivers, people $\underset{\mathbb{Q}}{\square}$ working in the cement industries and port services, ${ }^{15} \mathrm{O}$ and among workers exposed to welding fumes. ${ }^{16} \mathrm{~A}$ study in Connecticut found a significantly raised 
relative risk for machinists, ${ }^{17}$ and a non-specific association was found between laryngeal cancer and work as a non-construction labourer. ${ }^{18}$ Finally, a mortality study of workers employed in a refractory brick plant showed an increased standardised mortality ratio for laryngeal cancer among workers exposed to silica dust suggesting a role for exposure to silica in the aetiology of this cancer. ${ }^{19}$ In the present study excess of laryngeal cancer occurred among coal miners. This could be attributed to exposures to silica dust and oil mists. This point is discussed further below.

\section{COAL MINERS}

In our study coal miners were the only group in which three sites of URDT cancers appeared in excess. These were cancers of the lip, buccal cavity, and larynx. Working in coal mines involves specific exposures related to different habits of life style and presence of dusts, fumes, or vapours inside the galleries. Coal miners have reported making frequent use of chewing tobacco, a major risk factor for cancer of the buccal cavity. ${ }^{20} \mathrm{We}$ were unable, however, to quantify this association.

In the coal mines of the Nord-Pas de Calais region no exhaust fumes were present as no combustion engines were used. Industrial hygienists have recently been concerned with the presence of mineral oils used in hydraulic operations and mineral oils have been linked to laryngeal cancer. In addition to the raised relative risk among machinists already mentioned ${ }^{17}$ a study of subsequent primary tumours among 288 men with scrotal cancers, most likely induced by cutting oils, found a significant excess of tumours of the larynx, lip, bronchus, stomach, and skin. ${ }^{21}$

Several mortality studies have been conducted among coal miners. An excess of stomach cancer has been found, but no associations with the sites studied here. ${ }^{22}$ This might be due to competing risks which were stronger in earlier decades. It is also possible that we were able to show such associations because of the high proportion of coal miners (up to $20 \%$ of the workforce in the 1950s in Nord-Pas de Calais) in a community where patients with URDT cancers were easily accessible because of the high background rate, due probably to alcohol drinking habits in the region.
We thank Laurence Mandereau for technical help and Evelyne Przybilski for typing the manuscript.

1 Moulin JJ, Mur JM, Cavelier C. Epidémiologie comparée, en Europe, des cancers liés au tabac (poumon, larynx, pharynx, cavité buccale). Bull Cancer 1985;72:155-8.

2 Waterhouse J, Muir C, Shanmugaratham K, Powell J, eds Cancer incidence in five continents. Vol IV. Lyon: International Agency for Research on Cancer, 1982. (IARC sci publ No 42.)

3 Rezvani A, Doyon F, Flamant R, eds. Atlas de la mortalité par cancer en France (1971-1978). Paris: INSERM, 1986.

4 Tuyns AJ, Pequignot G, Jensen OM. Le cancer de l'oesophage en Ile-et-Vilaine en fonction des niveaux de consommation d'alcool et de tabac. Des risques qui se multiplient. Bull Cancer 1977;64:45-60.

5 Breslow NE, Day NE. Statistical methods in cancer research. Vol 1. The analysis of case-control studies. Lyon: International Agency for Research on Cancer, 1980. (IARC sci publ No 32.)

6 International Agency for Research on Cancer. Monographs on the evaluation of the carcinogenic risk of chemicals to humans. Vol 25. Wood, leather and some associated industries. Lyon: IARC, 1981.

7 Lindqvist C. Risk factors in lip cancer: a questionnaire survey. Am J Epidemiol 1979;109:521-30.

8 Moss E, Lee WR. Occurrence of oral and pharyngeal cancers in textile workers. Br J Ind Med 1974;31:224-32.

9 Whitaker CJ, Moss E, Lee WR, et al. Oral and pharyngeal cancer in the north-west and west Yorkshire regions of England, and occupation. Br J Ind Med 1979;36:292-8.

10 Decoufle $\mathrm{P}$. Cancer risks associated with employment in the leather and leather products industry. Arch Environ Health 1979;34:33-7.

11 Elwood JM, Pearson JCG, Skippen DH, et al.Alcohol, smoking, social and occupational factors in the aetiology of cancer of the oral cavity, pharynx and larynx. Int $J$ Cancer 1984;34: 603-12.

12 Moulin JJ, Mur JM, Wild P, et al. Oral cavity and laryngeal cancers among man-made mineral fiber production workers. Scand J Work Environ Health 1986;12:27-31.

13 Rothman KJ, Cann CI, Flanders D, et al. Epidemiology of laryngeal cancer. Epidemiol Rev 1980;2:195-209.

14 Flanders WD, Cann CI, Rothman KJ. Work-related risk factors for laryngeal cancer. Am J Epidemiol 1984;119:23-32.

15 Olsen J, Sabroe S. Occupational causes of laryngeal cancer. J Epidemiol Community Health 1984;38:117-21.

16 Olsen J, Sabroe S, Lajer M. Welding and cancer of the larynx: a case-control study. Eur J Cancer Clin Oncol 1984;20: 639-43.

17 Zagraniski RT, Kelsey J, Walter SD. Occupational risk factors for laryngeal carcinoma: Connecticut, 1975-1980. Am J Epidemiol 1986;124:67-76.

18 Brownson RC, Chang JC. Exposure to alcohol and tobacco and the risk of laryngeal cancer. Arch Environ Health 1987;42: $192-6$.

19 Puntoni R, Goldsmith DF, Vercelli M, et al. A cohort study of workers employed in a refractory brick plant. Scand $J$ Work Environ Health 1987;2:162.

20 International Agency for Research on Cancer. Monographs on the evaluation of carcinogenic risk of chemicals to humans. Vol 37. Tobacco habits other than smoking. Lyon: IARC, 1985.

21 Waldron HA. The carcinogenicity of oil mist. $\mathrm{Br} J$ Cancer 1975;32:256-7.

22 Simonato L, Saracci R. Cancer occupational. In: Encyclopedia of occupational health and safety. Vol 1. Geneva: International Labour Office, 1983:369-75.

Accepted 13 November 1989 